Volume 8 No. 1, Januari-Juni 2021

P-ISSN: 2406-808X // E-ISSN: 2550-0686

https://journal.iainlangsa.ac.id/index.php/ikhtibar

https://doi.org/10.32505/ikhtibar.v8i1.622

\title{
PERAN KEPALA MADRASAH IBTIDAIYAH AL HUDA SLEMAN YOGYAKARTA DIMASA PANDEMI COVID 19
}

\author{
Suratiningsih $^{1}$, Slamet Subagya ${ }^{2}$ \\ ${ }^{1}$ Program Studi PGMI, Sekolah Tinggi Agama Islam Yogyakarta, ${ }^{2}$ Madrasah Ibtidaiyah Al-Huda \\ Sleman Yogyakarta \\ 1ningstaiyo@gmail.com,
}

\begin{abstract}
Abstrak
Penelitian ini bertujuan untuk mengetahui peran kepala Madrasah Ibtidaiyah Al Huda Sleman Yogyakarta di masa pandemi covid 19. Penelitian ini merupakan penelitian diskriptif. Subjek penelitian adalah seluruh keluarga besar MI Al Huda, dengan cara random sampling. Teknik pengumpulan data berupa observasi, wawancara dan dokumentasi. Teknik analisis data yang digunakan adalah deskriptif kualitatif. Hasil Penelitian sebagai berikut: pertama, kepala Madrasah Ibtidaiyah Al Huda telah berhasil memotivasi guru dan memonitoring pembelajaran secara daring. Kedua, Kepala Madrasah Ibtidaiyah Al Huda telah berhasil memberikan sosialisasi, bimbingan dan pendampingan kepada siswa selama belajar dirumah. Ketiga, Kepala Madrasah Ibtidaiyah Al Huda berhasil menggerakkan orang tua, komite, bekerjasama dengan kompita membantu dibidang sosial ekonomi kepada orang tua dan masyarakat sekitar.
\end{abstract}

Kata Kunci: Peran Kepala Madrasah, Covid 19

\begin{abstract}
The aim of this research is to determine the role headmaster of Madrasah Ibtidaiyah Al Huda Sleman Yogyakarta in the Covid 19 pandemic. This research is descriptive research. The research subjects are all members of Madrasah Ibtidaiyah Al Huda using random sampling. Data collection techniques are in the form of observations, interviews and documentations. The data analysis used in this research is descriptive qualitative. The results of the study are as follows: First, the headmaster of Al Huda Madrasah Ibtidaiyah has succeeded in motivating teachers and monitoring online learning. Second, the headmaster Madrasah Ibtidaiyah Al Huda has succeeded in providing socialization, guidance and assistance to students while studying at home. Third, the headmaster Madrasah Ibtidaiyah Al Huda succeeded in involving parents, committees, in collaboration with kompita to help parents and surrounding communities in the socioeconomic field.
\end{abstract}

Keywords: The Role of the headmaster of Madrasah, Covid 


\section{A. PENDAHULUAN}

Corona Virus Disease 2019 disebut covid-19. Virus ini ditemukan pada akhir Desember 2019. Dikota Wuhan China. Penyebaran virus ini sangat cepat. Hanya dalam beberapa bulan saja virus ini sudah menyebar dibeberapa negara di dunia termasuk di Indonesia. Kondisi ini mendorong beberapa negara menetapkan lockdown sebagai upaya mencegah penyebaran virus corona.Di Indonesia diberlakukan Pembatasan Sosial Berskala Besar (PSBB) untuk memutus rantai penyebaran virus corona. Corona virus adalah kumpulan virus yang menginfeksi saluran pernapasan. Virus ini bisa menyebabkan infeksi pernapasan ringan seperti flu dan bisa juga mengakibatkan infeksi pernapasan berat, seperti infeksi paru-paru(Pneumonia). Virus corona juga mengakibatkan tingkat kematian. Menurut data yang dirilis gugus tugas percepatan penanganan covid-19 Republik Indonesia, jumlah kasus terkonfirmasi positif hingga 6 juli 2020 adalah 63.749 orang dengan jumlah kematian 3.171 orang. Tingkat kematian (Case Fatality Rate) akibat covid19 adalah sekitar $5 \% .^{1}$

Pada masa pandemi covid 19 ini Kementerian Pendidikan dan Kebudayaan mengeluarkan surat edaran Nomor 15 Tahun 2020tentang pedoman penyelenggaraan belajar dirumah dalam masa darurat penyebaran corona virus diseases (covid 19). Surat edaran tersebut bertujuan untuk (1)memastikan pemenuhan hak peserta didik untuk mendapatkan layanan pendidikan selama darurat covid-19,(2) melindungi warga satuan pendidikan dari dampak buruk covid19, (3)mencegah penyenaran dan penularan covid-19 disatuan pendidikan, (3)memastikan pemenuhan dukungan psikososial bagi pendidik, peserta didik dan orang tua atau wali. ${ }^{2}$ Madrasah Ibtidaiyah sebagai salah satu satuan pendidikan harus melakukan pembelajaran dari rumah sebagai upaya memutus penularan covid 19. Tentunya hal ini merupakan tantangan baru yang dihadapi Madrasah Ibtidaiyah. Selama bertahun-tahun melaksanakan pembelajaran dengan tatap muka langsung dalam waktu yang relative singkat harus beradaptasi dengan pembelajaran secara daring.

Peran kepala madrasah dimasa pandemi covid 19 bukanlah hal yang mudah. Ini merupakan hal baru yang belum pernah terjadi ditahun-tahun sebelumnya. Kepala madrasah sebagai leader memegang peranan penting dalam pengambilan keputusan. Kepala Madrasah sebagai pengambil kebijakan di madrasah sangat menentukan kualitas pendidikan di madrasah. Menurut Mulyasa, sifat-sifat kepemimpinan dikategorikan menjadi tiga yaitu demokratis, otoriter, laissez-faire. ${ }^{3}$ Sifat demokratis merupakan kemampuan pemimpin untuk mengikutsertakan bawahan dalam pengambilan keputusan secara demokrasi. Pemimpin memiliki kemampuan memotivasi anggota dalam sebuah organisasi. Otoriter merupakan kepemimpinan yang menggunakan jabatan dan mengandalkan kekuatan pribadi dalam pengambilan keputusan. Mempengaruhi oranglain dengan cara memaksa. Sedangkan laissez- faire merupakan kepemimpinan dengan sifat memberikan kebebasan kepada bahawannya. Pemimpin memiliki peranan yang minimal dalam pengambilan keputusan. Sifat-sifat yang dimiliki pemimpin ini sangat berpengaruh pada kemajuan madrasah yang dipimpinnya.

\footnotetext{
1 Merry Dame Cristy Pane, https://www.alodokter.com/virus-corona, diakses hari Selasa,7 Juli 2020.

2 Surat Edaran Nomor 15 tahun 2020 tentang Pedoman Penyelengaraan belajar Dari rumah dalam masa darurat penyebaran corona virus disease (COVID 19).

3 Mulyasa, Manajemen Berbasis Sekolah, (Bandung: Remaja Rosdakarya, 2011), hal.116
} 
Dampak corona virus disease-2019 pada bidang pendidikan di kota Yogyakarta mulai bulan Maret 2020, khususnya di Madrasah Ibtidaiyah Al Huda. Seluruh aktivitas di Madrasah Ibtidaiyah Al Huda berganti dari yang biasanya dilakukan dengan tatap muka langsung. Dilakukan dengan oneline. Kondisi ini merupakan hal baru di Madrasah Ibtidaiyah Al Huda.Dari analisis masalah selama masa covid -19 ditemukan beberapa permasalahan sebagai berikut:

1. Permasalahan yang timbul dari guru. Guru belum siap untuk melaksanakan kegiatan pembelajaran secara oneline.

2. Permasalahan yang timbul dari siswa. Siswa belum terbiasa belajar secara oneline dirumah.

3. Permasalah dari fihak orang tua. Orang tua belum siap mendampingi putra/putrinya untuk belajar dirumah. Disamping itu beban ekonomi yang harus orang tua tanggung saat pandemi covid 19.

Berdasarkan beberapa permasalahan yang dihadapi maka, peran kepala Madrasah Ibtidaiyah Al Huda dimasa pandemi covid 19 sangat menentukan berhasil tidaknya dalam mengatasi beberapa permasalahan yang timbul.

Penelitian ini bertujuan untuk mengetahui peran kepala Madrasah Ibtidaiyah Al Huda Karang nongko, Depok, Sleman Yogyakarta dimasa pandemi covid 19. Berdasarkan beberapa latar belakang permasalahan yang dihadapi, kepala sekolah menjadi ujung tombak dalam mengambil beberapa kebijakan untuk mengatasi permasalahan tersebut.

Berikut ini beberapa kajian pustaka yang relevan dengan peran kepala Madrasah Ibtidaiyah dimasa pandemi covid 19.

1. Penelitian yang dilakukan oleh Wahyu Aji Fatma Dewi. Dengan judul Dampak covid 19 Terhadap Implementasi Pembelajaran Daring Di Sekolah Dasar. Dengan hasil sebagai berikut: Implementasi pembelajaran daring yang dilakukan disekolah dasar dapat berjalan dengan baik. Guru menggunakan beberapa aplikasi dalam melakukan pembelajaran daring, seperti ruang guru, class room, zoom, google doc, google form maupun Whatsap Group. Untuk kelas rendah dalam pembelajaran daring masih membutuhkan pendampingan dari orang tua. ${ }^{4}$

2. Penelitian yang dilakukan oleh Muhammad Sufyan. Dengan judul pengalaman baik selama FLH oleh Kepala sekolah. Dengan hasil sebagai berikut: Kegiatan disekolah berjalan dengan baik karena didukung oleh dinas pendidikan kota Surabaya dan bekerjasama dengan TV swasta.Pihak sekolah menjadwalkan setiap kegiatan dengan baik. Kerjasama dengan orang tua belum bisa maksimal dikarenakan banyak diantara orang tua yang harus bekerja. ${ }^{5}$

3. Luh Devi Herliandry, dkk. Dengan judul Pembelajaran Pada Masa Pandemi covid-19. Dengan hasil sebagai berikut: Dalam kondisi apapun pembelajaran secara oneline merupakan salah satu solusi yang dapat dilaksanakan. Kemudahan dalam transfer informasi dapat dilakukan secara oneline. ${ }^{6}$

${ }^{4}$ Wahyu Aji Fatma Dewi, Dampak Covid -19 Terhadap Implementasi Pembelajaran Daring Di Sekolah Dasar, Jurnal Edukatif, Ilmu pendidikan, Volume 2, April 2020,hlm.6

5 Muhammad Sufyan, Pengalaman Baik Selama FLH oleh Kepala Sekolah,(Jakarta:Direktorat jenderal guru dan tenaga Kependidikan kementerian pendidikan dan Kebudayaan, 2020), hlm.131.

6 Luh Devi Herliandry dkk, Pembelajaran Pada Masa Pandemi Covid 19,(Jakarta: Jurnal Teknologi Pendidikan, 2020), hlm.6. 


\section{B. METODE PENELITIAN}

Subjek dalam penelitian ini adalah seluruh keluarga besar Madrasah Ibtidaiyah Al Huda Karang nonggko, Maguwoharjo, Depok, Sleman, Yogyakarta.Yang terdiri dari kepala madrasah, guru, staf karyawan, siswa, dan orangtua. Teknik yang digunakan dalam pengambilan data dengan cara random sampling. Adapun yang menjadi objek penelitian adalah peran kepala Madrasah Ibtidaiyah Al Huda Sleman Yogyakarta dimasa pandemi covid 19.

Penelitian ini menggunakan metode deskriptif. Teknik pengumpulan data berupa observasi, wawancara dan dokumentasi. Observasi akan digunakan untuk mengamati peran kepala madrasah dimasa pandemi covid 19. Wawancara digunakan untuk mendapatkan berbagai informasi tentang peran kepala madrasah di masa covid 19 tersebut. Dokumentasi digunakan sebagai bukti nyata peran kepala madrasah di masa covid 19. Teknik analisis data yang digunakan adalah deskriptif kualitatif. Diskriptif kualitatif merupakan penelitian yang menghasilkan data berupa diskripsi yang berupa tulisan maupun lisan dari subjek yang diamati. ${ }^{7}$

\section{HASIL DAN PEMBAHASAN \\ 1. HASIL}

Berikut ini akan dipaparkan beberapa hasil penelitian tentang peran kepala Madrasah Ibtidaiyah Al Huda dimasa pandemi covid 19. Berdasarkan data hasil penelitian yang telah disusun peneliti. Hasil penelitian terdiri dari tiga bagian penting, pertama, peran kepala Madrasah Ibtidaiyah Al Huda dalam mengatasi permasalahan guru dimasa pandemi Covid 19. Kepala madrasah telah berhasil memotivasi guru dan memonitoring pembelajaran yang telah dilakukan selama pembelajaran dirumah secara daring. Dari hasil yang diperoleh guru-guru MI Al Huda dengan waktu yang singkat dapat melaksanakan proses pembelajaran secara daring. Menggunakan aplikasi secara oneline. Dalam waktu tiga hari guru-guru MI Al Huda sudah mampu memberikan materi, membuat soal, mengevaluasi dan menganalisis hasil dari pembelajaran.

Kedua, Peran kepala Madrasah Ibtidaiyah dalam mengatasi masalah siswa yang belum terbiasa belajar secara oneline dirumah. Kepala Madrasah Ibtidaiyah Al Huda Slamet Subagya telah berhasil mengatasi permasalah tersebut. Siswa-siswi yang awalnya belum terbiasa melaksanakan pembelajaran secara oneline dengan mengikuti sosialisasi, bimbingan dan pendampingan mampu melaksanakan pembelajaran secara oneline dirumah masing-masing. Siswa kelas bawah kelas satu, dua dan tiga dalam melaksanakan pembelajaran dirumah didampingi orangtuanya. Memanfaatkan WhatsApp Group dalam memberikan pembelajaran. Sedangkan untuk siswa-siswi kelas atas kelas empat, lima dan enam menggunakan aplikasi yang telah disediakan sekolah. Siswa- siswi kelas atas sudah mampu melaksanakan pembelajaran secara oneline dengan mandiri tanpa bantuan orang tua mereka.

Ketiga, Peran kepala Madrasah Ibtidaiyah Al Huda dalam mengatasi permasalan dari orang tua. Dari hasil observasi dilapangan peran kepala Madrasah Ibtidaiyah Al Huda sangatlah besar. Kepala Madrasah mampu menggerakkan seluruh warga sekolah untuk bersatu saling membantu. Orang tua yang belum mampu mendampingi putra-putrinya belajar secara oneline diberikan sosialisasi dan pendampingan. Disamping itu bentuk dari

\footnotetext{
${ }^{7}$ Moleolong L.J, Metodologi Penelitian Kualitatif,(Bandung:Remaja Rosdakarya, 2017),hal.5
} 
perhatian warga sekolah terhadap orang tua dan masyarakat yang terkena dampak covid 19. Madrasah bekerjasama dengan komite dan KOMPITA memberikan bantuan berupa sembako sebagai bahan makanan pokok. Madrasah Ibtidaiyah Al Huda juga memberikan bantuan berupa keringanan biaya pendidikan, bahkan ada yang digratiskan. Memberikan modal usaha bagi orang tua yang terkena dampak PHK.

\section{PEMBAHASAN}

Kepala Madrasah merupakan salah satu komponen pendidikan yang paling berperan dalam menentukan keberhasilan suatu lembaga pendidikan. ${ }^{8}$ Peran kepala madrasah dalam menjalankan tugasnya dapat dinilai dari kinerjanya dalam menjalankan fungsi dan perannannya sebagai kepala sekolah. Adapun fungsi dan peran kepala madrasah menurut Marno, Pertama, sebagai pendidik (educator). Dalam hal ini kepala madrasah mampu membimbing guru dalam melaksanakan tugasnya. Mampu memberikan beberapa alternative dalam melaksanakan pembelajaran yang efektif. Disamping itu juga mampu membimbing bermacam-macam kegiatan kesiswaan. Kedua,sebagai manajer, kepala madrasah memiliki kemampuan untuk menyusun organisasi personal dengan uraian tugas sesuai dengan standar yang ada. Kepala Madrasah memiliki kemampuan untuk menggerakkan stafnya dan segala sumber daya yang ada dan memberikan acuan yang dinamis dalam kegiatan rutin dan temporer. Selanjutnya memiliki kemampuan untuk menyusun program secara sistematis dan memiliki kemampuan sebagai supervisor. ${ }^{9}$ Sedangkan teori kepemimpinan menurut Isjoni menjelaskan bahwa teori kepemimpinan dikelompokkan menjadi dua. Teori kepemimpinan kharismatik (charis matic leadership) dan teori kepemimpinan transformasional (transformational leadership). Kepemimpinan kharismatik memiliki beberapa ciri khas diantaranya: memiliki visi yang amat kuat atau kesadaran tujuan yang jelas, mampu mengkomunikasikan visi itu dengan efektif, mampu mendemonstrasikan konsistensi dan fokus, mengetahui kekuatan-kekuatan sendiri dan memanfaatkannya. Sedangkan untuk pemimpinpemimpin transformasional membimbing atau memotivasi stafnya kearah tujuan yang telah ditentukan dengan cara menjelaskan ketentuan-ketentuan peran dan tugas-tugasnya. Pemimpin transformasional memberikan pertimbangan yang bersifat individual, stimulasi inteektual dan memiliki kharismatik. ${ }^{10}$

Moralitas pemimpin yang digambarkan dalam islam sebagai pedoman untuk menjadi pemimpin yang baik diantaranya sebagai berikut:

a. Adil.

Dijelaskan dalam Al Qur'an Surat An Nisa ayat 58 yang artinya:

"Sungguh Allah menyuruhmu menyampaikan amanat kepada yang berhak menerimanya, dan apabila kamu menetapkan hukum diantara manusia hendaknya kamu menetapkannya dengan adil. Sungguh Allah sebaik-baik pemberi pengajaran kepadamu. Sungguh, Allah maha Mendengar, Maha Melihat",11

b. Fatonah, memiliki kecerdasan dan mampu memberikan ide dan gagasan yang cemerlang. Dalam menyikapi seluruh permaslahan yang ada.

\footnotetext{
${ }_{9}^{8}$ E Mulyasa, Menjadi Kepala Sekolah Profesional,(Bandung: PT Remaja Rosda karya,2004),hlm.24

9 Marno, Triyo Suppriyatno, Manajemen dan Kepemimpinan Pendidikan Islam, (Bandung: Refika Aditma,2008),hlm.39

10 Isjoni, Manajemen Kepemimpinan dalam Pendidikan, (Bandung: Sinar Baru Algensindu,2007),hlm.33

11 Al Qur'an dan Terjemahan, (Bandung: JABAL, 2010),hlm.87
} 
c. Tabligh, memiliki kemampuan untuk menyampaikan dengan benar.

d. Sabar, Memiliki kesabaran dalam mengendalikan hawa nafsu. Menyikapi setiap permasalah yang ada.

e. Siasah, yaitu pandai mengatur strategi guna mendapatkan kemajuan dan kebaikan bagi seluruh warga nya.

Peran Kepala Madrasah Al Huda Di Masa Pandemi covid 19. Tugas dan tanggung jawab kepala madrasah salah satunya adalah mengelola sumberdaya manusia yang ada dimadrasah yang terdiri dari guru dan staf karyawan sehingga menjadi sumber daya manusia yang mampu dioptimalkan. Kepala Madrasah Ibtidaiyah memiliki jiwa kepemimpinan yang demokratis, memiliki kepribadian yang baik, santun, ramah dan selalu memperhatikan seluruh warga Madrasah. Disamping itu kepala Madrasah Ibtidaiyah Al Huda Sleman Yogyakarta memiliki jiwa kepemimpinan visioner. Menurut Wahyudi kepemimpinan visioner (visionary Leadership) adalah kemampuan pemimpin untuk mencetuskan ide-ide dan gagasan-gagasan suatu visi dan mampu mengkomunikasikan secara kritis ${ }^{12}$. Disamping itu kepala Madrasah Ibtidaiyah Al Huda juga mampu menjalin kerjasama dengan fihak-fihak terkait dengan membuat MoU dalam mewujudkan visi, misi dan tujuan yang ada di Madrasah Ibtidaiyah Al Huda. Kemampuan kepala Madrasah inilah yang mampu menggerakkan semua warga madrasah berperan aktif sesuai dengan tugastugasnya, sehingga dimasa pandemi covid 19 ini Madrasah Ibtidaiyah Al Huda tetap bisa eksis ditengah pandemi. Madrasah Ibtidaiyah Al Huda juga mampu berkontribusi membantu masyarakat sekitar dalam masa pandemi covid 19 ini.

Kebijakan Kepala Madrasah Ibtidaiyah Al Huda dalam menghadapi permasalah yang timbul melakukan beberapa tindakan sesuai dengan kebutuhan fihak-fihak terkait. Permasalahan yang muncul dari fihak guru. Guru belum siap untuk melaksanakan kegiatan pembelajaran secara oneline. Menyikapi permasalahan tersebut kepala Madrasah Ibtidaiyah Al Huda Bapak Slamet subagya, M.Pd menjelaskan beliau menyusun perencanaan dengan sungguh-sungguh. Mengadakan forum guru untuk belajar bersama dengan menghadirkan nara sumber yang ahli dibidang IT. Dalam forum tersebut guru dilatih, dibimbing untuk mampu melaksanakan pembelajaran secara oneline. Selama tiga hari guru dilatih untuk mampu melaksanakan proses pembelajaran secara oneline, membuat tugas-tugas, evaluasi dan menganalisis proses pembelajaran yang telah dilakukan. Dari forum guru yang telah dilakukan menghasilkan guruguru yang sebelumnya tidak pernah melaksanakan pembelajaran secara oneline kini mampu melaksanakan pembelajaran secara oneline. Dalam hal ini pelatihan guru memegang peranan penting untuk dapat meningkatkan kompetensi guru dalam melaksanakn pembelajaran.

Pembelajaran secara oneline merupakan hal baru bagi siswa-siswi Madrasah Ibtidaiyah Al Huda. Dimasa pandemi covid 19 ini, untuk memutus mata rantai penyebaran covid 19 siswa-siswi harus belajar secara one line dirumah. Peran kepala madrasah dalam menghadapi Permasalan dari siswa yang belum mampu melaksanakan pembelajaran secara one line dengan melakukan sosialisasi.Memberikan pengarahan dan penjelasan bagi siswa dalam memanfaatkan aplikasi untuk melaksanakan pembelajaran dirumah secara daring. Siswa kelas rendah yaitu kelas satu, dua, dan tiga karena mereka masih kecil pembelajaran yang dilakukan melibatkan peran serta orang tua dengan menggunakan Whatsup Group. Sedangkan untuk siswa kelas atas kelas empat, lima dan enam sudah mampu melaksanakan pembelajaran oneline secara mandiri. Dengan demikian pembelajaran oneline yang dilaksanakan di MI Al Huda dapat berjalan dengan baik.

12 Wahyudi,Kepemimpinan Kepala Sekolah Dalam Organisasi Pembelajar, (Bandung: Alfabeta, 2012), hlm.15. 
Peran kepala Madrasah Ibtidaiyah Al Huda dalam menghadapi permasalahan terhadap orang tua siswa di masa pandemi covid 19. Pada awal kebijakan pemberintah bahwa siswa belajar dirumah memberikan masalah baru bagi orang tua siswa. Banyak dari orang tua siswa yang belum paham tentang pembelajaran secara oneline. Menyikapi permasalahan tersebut, kepala Madrasah Ibtidaiyah bekerja sama dengan guru dan komite memberikan sosialisasi tentang proses pembelajaran yang akan dilakukan di rumah. Orang tua diberikan penjelasan , bimbingan dan pendampingan dalam mendampingi putra-putri nya pada saat melaksanakan pembelajaran secara oneline. Komunikasi dan kerjasama yang baik antara kepala sekolah, guru dan komite menghasilkan suasana yang lebih kondusif. Orang tua mampu memahami proses pembelajaran secara oneline. Dengan demikian proses pembelajaran di Madrasah Ibtidaiyah Al Huda pada masa pandemi covid 19 ini dapat terlaksana dengan baik.

Covid 19 memberikan dampak luar biasa yang menimbulkan permasalah di bidang sosial ekonomi yang dialami orang tua siswa-siswi Madrasah Ibtidaiyah. Sebagai wujud kepedulian terhadap orangtua siswa dan masyarakat sekitar yang terkena dampak covid 19. Kepala Madrasah Ibtidaiyah Al Huda Slamet Subagya, M.Pd bekerjasama dengan KOMPITA (Komunitas Indonesia Pintar) dan komite memberikan bantuan berupa paket sembako. Kegiatan ini bertajuk Sedekah membawa berkah yang dilaksanakan pada hari Jum'at, 1 Mei 2020. Kegiatan ini sekaligus untuk memperingati hari pendidikan nasional dan jum'at berkah. Dalam kegiatan ini membagikan sejumlah 160 paket sembako kepada orang tua siswa yang terkena dampak covid 19 dan masyarakat sekitar yang kurang mampu. Program selanjutnya yang dilakukan MI Al Huda dimasa pandemi covid 19 ini juga memberikan bantuan berupa modal usaha bagi orang tua yang kehilangan pekerjaannya. Menurut Farida salah satu penggerak KOMPITA mengatakan bahwa KOMPITA telah menjalin kerjasama dengan MI Al Huda terutama memberikan bantuan kepada siswa yang kurang mampu, memberikan beasiswa kepada siswa yatim piatu. Dalam kegiatan ini Madrasah Ibtidaiyah tetap melaksanakan pencegahan covid 19 dengan menerapkan physical distancing. ${ }^{13}$

\section{KESIMPULAN DAN SARAN}

Berdasarkan data yang telah dipaparkan. Peran kepala Madrasah Ibtidaiyah Al Huda dalam mengatasi permasalahan dimasa pandemi covid 19 sangatlah besar. Kepala Madrasah memiliki tanggung jawab yang baik. Kemampuan kepala Madrasah Ibtidaiyah Al Huda dalam membuat perencanaan, mengorganisir, menggerakkan dan mengontrol setiap kegiatan sudah dilakukan dengan baik. Dengan kemampuan yang dimiliki kepala Madrasah Ibtidaiyah Al Huda permasalahan guru, siswa dan orang tua dapat diselesaikan dengan baik. Kegiatan- kegiatan yang dilakukan dalam mengatasi permasalahan yang dihadapi sudah cukup baik. Hal ini perlu didukung oleh seluruh warga madrasah agar dapat berjalan dengan maksimal.

\footnotetext{
${ }^{13}$ Tribunjogja.com Dengan Judul MI Al Huda Bagikan Sembako Pada Wali Murid Dan Warga, Https://Jogja.Tribunnews.Com/2020/05/01/Mi-Al-Huda-Bagikan-Sembako-PadaWali-Murid-Dan-Warga
} 


\section{DAFTAR PUSTAKA}

Al Qur'an dan terjemahannya. Bandung: JABAL,2010.

Dwi, W. A, Dampak Covid 19 Terhadap Implementasi Pembelajaran Daring di Sekolah Dasar. Jurnal Edukatif , 6, 2020.

Herliandry, L. D, Pembelajaran Pada Masa Pandemi covid 19. Jurnal: Teknologi Pendidikan , 6, 2020.

Isjoni, Manajemen Kepemimpinan Dalam Pendidikan. Bandung: Algensindu, 2007.

Marno, Supriyatno Triyo, Manajemen dan kepemimpinan Pendidikan Islam. Bandung: Refika Aditma, 2008.

Moeolong, Metodologi Penelitian Kualitatif. Bandung: Remaja Rosdakarya, 2017.

Mulyasa, E. Manajemen Berbasis Sekolah. Bandung: Rosdakarya, 2011

, Menjadi Kepala Sekolah Profesional. Bandung: Rosdakarya, 2004.

Pane, M. D. (n.d.). https: www.alodokter.com/virus-corona.

Kementrian Pendidikan dan Kebudayaan, Surat Edaran Nomor 14 Tahun 2020 Tentang Pedoman Penyelenggaraan Belajar di Rumah dalam Masa Darurat Penyebaran Virus disease (covid 19), 2020

Sofyan, M, Pengalaman Baik Selama FLH oleh Kepala Sekolah. Jakarta: Direktorat Jenderal Guru dan Tenaga Kependidikan Kementerian Pendidikan dan Kebudayaan, 2020.

Tribunjogja.com, MI Al Huda Bagikan Sembako Pada Wali Murid dan Warga. Yogyakarta: https://jogja, Tribunnews.com, 2020

Wahyudi, Kepemimpinan Kepala Sekolah Dalam Organisasi. Bandung: Al fabeta, 2012. 